
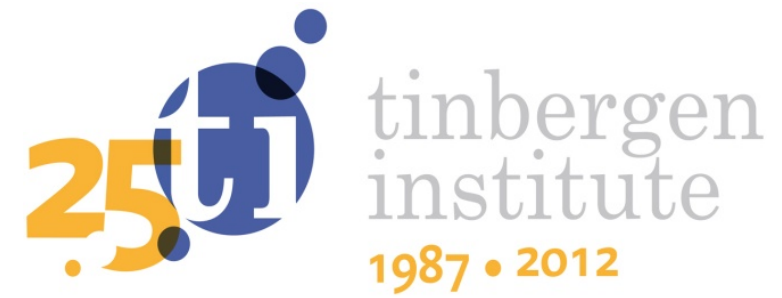

\title{
Adoption of Electric Vehicle in the Netherlands - \\ A Stated Choice Experiment
}

\author{
M. Bočkarjova ' \\ P. Rietveld 1,2 \\ J.S.A. Knockaert ${ }^{1}$
}

${ }^{\prime}$ Faculty of Economics and Business Administration, VU University Amsterdam;

2 Tinbergen Institute. 
Tinbergen Institute is the graduate school and research institute in economics of Erasmus University Rotterdam, the University of Amsterdam and VU University Amsterdam.

More TI discussion papers can be downloaded at http://www.tinbergen.nl

Tinbergen Institute has two locations:

Tinbergen Institute Amsterdam

Gustav Mahlerplein 117

1082 MS Amsterdam

The Netherlands

Tel.: +31(0)205251600

Tinbergen Institute Rotterdam

Burg. Oudlaan 50

3062 PA Rotterdam

The Netherlands

Tel.: +31(0)10 4088900

Fax: $+31(0) 104089031$

Duisenberg school of finance is a collaboration of the Dutch financial sector and universities, with the ambition to support innovative research and offer top quality academic education in core areas of finance.

DSF research papers can be downloaded at: http://www.dsf.nl/

Duisenberg school of finance

Gustav Mahlerplein 117

1082 MS Amsterdam

The Netherlands

Tel.: +31(0)20 5258579 


\title{
Adoption of Electric Vehicle in the Netherlands a Stated Choice Experiment
}

\section{Marija Bočkarjova}

VU Amsterdam, Faculty of Economics and Business Administration, Department of Spatial Economics, de Boelelaan 1105, 1081 HV Amsterdam, The Netherlands. Email: m.bockarjova@vu.nl , tel. +31 20598 6142, fax +31 205986004 (corresponding author)

Piet Rietveld

VU Amsterdam, Faculty of Economics and Business Administration, Department of Spatial Economics, de Boelelaan 1105, 1081 HV Amsterdam, The Netherlands. Email: p.rietveld@vu.nl

Jasper S.A.Knockaert

VU Amsterdam, Faculty of Economics and Business Administration, Department of Spatial Economics, de Boelelaan 1105, 1081 HV Amsterdam, The Netherlands. Email:

jasper.knockaert@vu.nl

\begin{abstract}
In this paper, we develop a dynamic innovation diffusion framework to model adoption of full electric vehicles in the Netherlands. Three major phases of adoption are distinguished: introduction, growth and maturity. Adoption stages are further integrated into an SP study to elicit individual preferences for conventional, hybrid and full electric vehicles. We apply a nested logit model to estimate the preferences for EVs based on the generalised costs of ownership approach that includes monetary and non-monetary costs of owing a vehicle.

With positive estimates of WTP for hybrid vehicles (of about $€ 900$ on a yearly basis), our results suggest abolishment of subsidization of hybrid vehicles as they potentially crowd out $\mathrm{EV}$ adoption. Time costs associated with rapid charging are a substantial hindrance to EV adoption with average value of time of $€ 63$ per hour, increasing for each subsequent consumer segment from $€ 48$ to $€ 122$ per hour. Environmental costs of $\mathrm{CO} 2$ reductions are valued far above the market average at $€ 160$ per ton, but determine EV choices only at a later stage of adoption. Finally, towing potential is valued on average at $€ 540$ per year and it is about the same for all consumer segments throughout the adoption phases. Policy implications are discussed involving a mix of structural and monetary incentives.
\end{abstract}

Key words: stated preferences, revealed preferences, non-monetary costs, innovation.

\section{Introduction}

Electric mobility is in its initial stage to penetrate the automobile markets. Experts and scientists agree that EVs at this stage possess inferior technical characteristics (such as limited range and towing potential). Besides, EVs have higher purchase price on average of about $150 \%$ relative to a comparable conventional fuel model. Combined, an EV when compared to a conventional vehicle, unanimously looses in terms of two important consumer attributes, functionality and price (for example, Dimitropoulos et al. 2012 found that, ceteris paribus, a full electric vehicle with a $150 \mathrm{~km}$ range should cost $60 \%$ less than a similar conventional vehicle). At the same time, the benefits of an EV are continuously debated. Among potential advantages, low operational costs, 
zero tailpipe emissions of $\mathrm{CO}_{2}$ and particulate matter, noise reduction, and, given sustainable energy production, lower carbon emissions over the whole vehicle lifecycle compared to conventional fuel vehicles are mentioned, as well as decreased reliance on fossil fuels. In such a situation, it is not difficult for a consumer to become persuaded that an EV is a type of vehicle that possesses a number of certain tangible disadvantages that mainly incur individual costs, and a number of intangible advantages that are less certain and that should mainly bring collective benefits.

At the same time, governments around the globe have embraced EVs together with other alternative fuel vehicles as a step towards a more sustainable mobility, and introduced multiple incentives to speed up EV introduction. Essentially, most of the implemented incentives included financial schemes aiming at reducing the monetary disadvantages connected to high upfront costs of EVs. Despite these efforts, recent research shows that monetary incentives have repeatedly failed to achieve desirable results so far in terms of EV adoption rates (Chandra et al., 2010; Beresteanu and Li, 2011), and have in some instances lead to disproportionate distributional effects. The majority of consumers thus far do not readily consider a full electric vehicle as a better substitute for a conventional fuel car.

Perhaps one of the main questions that can be asked in this relation is: Why have incentives so far failed to attract drivers to EV? Other questions may include: Have monetary incentives been too weak or lasted too short? Have monetary incentives been accompanied by appropriate non-monetary incentives? Has the (main) functional limitation concerning range been appropriately addressed? Have the advantages of EVs been appropriately utilized? Essentially, these questions call for a more inclusive approach with monetary and non-monetary elements to analyze EV adoption, considering its purchase as well as possession.

Some recent studies take yet another approach and consider EV advantages and disadvantages during the entire lifecycle of the vehicle. They mainly take account of production, consumption/use and disposal phases of the EV lifecycle (see for example Howard et al., 2012). These studies provide useful insights into the relative advantages of the vehicle compared to its conventional alternative. Because such approaches focus on the entire vehicle lifecycle, they are not relevant to consumers to support their decision-making concerning the purchase of a vehicle for a limited time period. Other approaches, mainly from the practice domain, point at the importance of focusing on the so-called total costs of ownership (TCO, van Vliet et al. 2011; RAI 2011). TCO-type of approach is often proposed to circumvent the inherent consumer myopia for the high EV purchasing costs, and to demonstrate financial advantages that are connected to EV use such as low operational costs, depreciation, maintenance, insurance, taxes and tax refunds and reliefs. Although existing TCO approaches take explicit account of various monetary costs associated with vehicle purchase and use, they often ignore non-monetary costs, which are also part of consumer decision-making. In this paper, we provide a first attempt at closing this gap. We apply a generalized vehicle ownership cost approach to specify utility that is similar to generalized cost approach in transport studies (Small and Verhoef, 2007). Generalized cost of ownership (GCO) as proposed in this paper, accounts for tangible and intangible benefits of EVs in comparison to a conventional vehicle and is applied within a temporal frame that is relevant to vehicle purchase. We thus estimate 
individual preferences for vehicle choices based on generalized monetary costs, as well as on costs of time associated with charging, environmental costs associated with $\mathrm{CO} 2$ emissions, and extra facilities such as towing potential of a vehicle. This approach should help better understand consumer motivation for EV adoption, which can in turn help guide policy facilitating EV adoption.

Besides, for the introduction of a new product on the market, it is essential to recognize the heterogeneity of consumers, which is not only cross-sectional but also possesses time-dependent dynamics during the whole cycle of adoption. Several models of market penetration of alternative vehicles have already been presented (like Eggers \& Eggers 2011; Struben \& Sterman 2008), other researchers paid more attention to the types of consumers (Zhang et al. 2011; Lieven et al. 2011). However, so far presented approaches seldom included both elements simultaneously, the product and consumers, interacting in a dynamic market. In this paper we aim at addressing this issue and present a dynamic vehicle adoption model. The proposed model is conceptually drawn on the theory of diffusion of innovation (Rogers, 2000) and is given its analytical form within a stated preference study. The model takes explicit account of consumer heterogeneity as well as product development throughout the entire vehicle adoption cycle. We thus assume that the whole process of adoption involves a number of stages, so that various adopter segments enter the market at different moments in time and have distinctive product requirements. At the same time, each following segment faces a slightly different (improving) product under evolving market conditions. Presented model should help understand consumer needs for each consumer segment and design better policy for a smooth progression through the entire adoption process from product introduction to the market, to the growth and the maturity phases.

This paper is structured as follows: we discuss innovation adoption process in Section 2. Section 3 introduces the SP experiment. Section 4 describes the statistical model and the model specification. Section 5 deals with the data and the sample. Section 6 follows with results and Section 7 finalises the paper with discussion, conclusions and policy implications.

\section{Methodology}

\subsection{Product Adoption and Consumer Segments}

One of the theories that describes introduction of an innovative product to the market is the theory of Diffusion of Innovation (Rogers, 1995 and 2000). The theory consists of four elements. The first element is innovation, and tackles the novel product itself, its characteristics and development through the adoption cycle. The second element is communication channels that consist of formal and informal channels and plays an important role in dissemination of information about the new product, persuasion of potential customers and encouragement in behavior. The third element is social context that includes social structure and system norms that may also facilitate as well as hinder adoption of a novel product. The final, fourth element of the theory is time and it has three sub-elements: consumer segments, rate of adoption and decision stages. In this paper, we shall focus on this last element of the Diffusion of innovation 
theory, and in particular on the pace of adoption and the consumer segments, which we shall explain below.

The time dimension is crucial in innovation diffusion. It explicitly recognizes not only that adoption of a new product is heterogeneous, but also that this heterogeneity has an explicit time dynamics such that different consumers enter the market at different points in time, and are offered an ever developing version of the innovative product. In particular, Rodgers' theory distinguishes 5 types of consumers, or consumer segments with the following ideal type characteristics:

Innovators - venturesome, well-informed risk takers who are willing to try an unproven product;

Early adopters - educated opinion leaders; envision important future applications of new technology and want to be the first to profit from it; are willing to experiment and pioneer its use;

Early majority - understand the new technology, but are practical; need to be confident about the benefits; mostly rely on recommendations of other users;

Late majority - skeptical consumers who acquire an established product after it has become commonplace; need to see obvious benefits;

Traditionalists or laggards - conservative and distrustful of new technologies; avoid change and may not adopt a new product until forced or until traditional alternatives are no longer available.

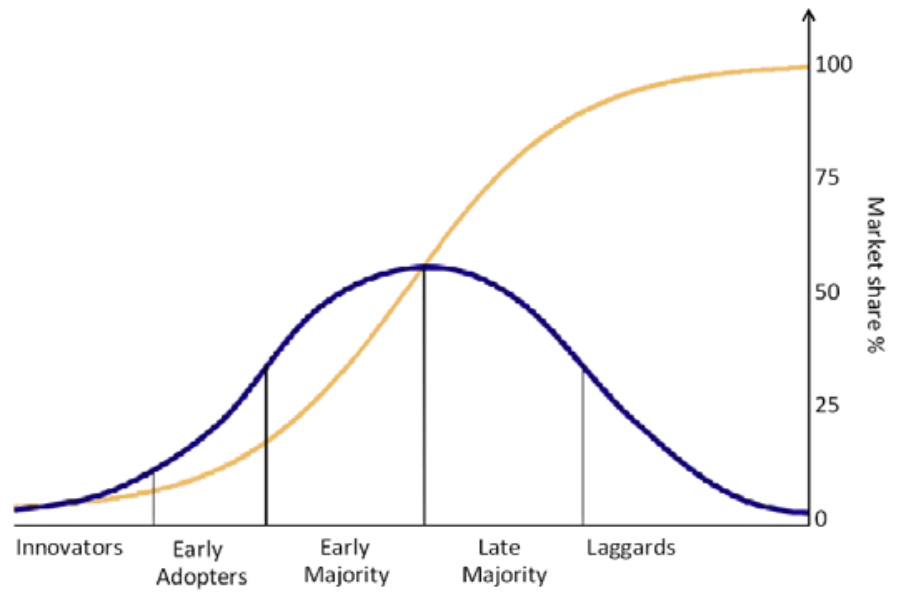

FIGURE 1. Rate of innovation adoption with adopter categorizations and a cumulative rate of adoption (the S-shaped curve).

Following the literature in the field of innovation diffusion (Rogers 2000, Hill \& Jones 2009), consumers across the segments have different socio-economic and psychographic characteristics and they differ in their motivations concerning the purchase of a novel product. This means that they may strive to satisfy different needs and form different preferences with respect to the same product. Therefore, different consumers would require different incentives to stimulate new product adoption.

Furthermore, consumer segments not only have different psychological and socio-economic profiles (Rogers 2000), they are also different in size. So, Innovators 
would make up the smallest group of all adopters; Early Adopters and Traditionalists will be more numerous, but as yet not as sizeable as Early Majority and Late Majority. This means that the rate of adoption is not constant, but rather resembles an S-shape (see Figure 1). At the starting phase it will be relatively flat, where the product is 'tested' by the Innovators and the Early Adopters (this phase is also sometimes referred to as the embryonic market). If the product is successful and is adopted by the Early Majority segment, the rate of adoption becomes steep, and the product is effectively going large and enters the mass market, where sales continue to grow throughout the Late Majority segment and are flatting down again when traditionalists are picking up with the rest of the fellow consumers.

Consumers across the segments have different socio-economic and psychographic characteristics and they differ in their motivations concerning the purchase of a novel product (Rogers 2000, Hill \& Jones 2009). This means that they may strive to satisfy different needs and form different preferences with respect to the same product. The crucial moment in the adoption process is transition between the Early Adopters and the Early Majority segments where some products enjoy successful take-off, while others suffer a decay in sales. Literature suggests that often this is due to inability to match product characteristics with consumer needs as the product progresses from the niche markets with Early adopters to the mass market where a different type of consumer is engaged, the Early majority. This phenomenon is called a "chasm" (Hill \& Jones 2009, as well as Moore 1991, Utterback 1994; De Marez Lieven \& Verleye Gino 2004). Besides, the product itself experiences quality evolution during the diffusion process. New products are often technically inferior to the products sold on the market at the later stages of adoption (for example, computers, mobile phones, camera's, home appliances, cars). To summarise, for the product to be successful, it should possess such characteristics that meet the needs of the particular consumer segment at a particular point in time. As a consequence, different consumers would need different incentives to stimulate new product adoption. ${ }^{1}$

\subsection{Generalized Cost of Ownership}

Alternative fuel vehicles have raised a lot of scientific interest which has lead to a vast amount of literature covering various aspects of AFV introduction to the market currently dominated by conventional fossil fuel vehicles. This literature includes technical and technological aspects (among others, Ito et al., 2013), environmental impact of AFVs (among others, Delucchi et al., 1989, Funk and Rabl, 2002, Hawkins et al., 2012), analysis of preferences and demand for AFVs (for a review, see Dimitropoulos et al., 2012), and psychological aspects of AFV adoption (Maua et al., 2008; Axsen et al., 2010; Franke et al., 2012, Schuitema et al., 2013). In determining demand for alternative vehicles, often approaches are used that apply revealed or stated preference (SP) techniques, or a combination of both. When SP methods are applied, implied utilities are specified that are based on preferences for shown vehicle attributes, from which coefficient estimates are obtained. Willingness to pay

\footnotetext{
${ }^{1}$ The temporal path of adoption may vary substantially across various types of products; vehicle diffusion appears to measure a number of decades and needs to be appropriately steered during this longitudinal adoption process (Struben and Sterman 2008). We shall return to this issue.
} 
estimates are then based on an estimated monetary coefficient that is usually based on one-time payments such as purchasing price (Dimitropoulos et al., 2012). Such studies provide valuable insight into the preference for vehicle attributes relative to purchasing price; however, such approaches rarely take account of such decisionmaking aspects as the expected vehicle depreciation or expected purpose of vehicle use, which are often make explicit part of vehicle purchase. These and other characteristics are often used as covariates in utility specifications to capture preference heterogeneity, but this way do not reflect decision-making process.

Yet other aspects that are shown to be important in vehicle choice are such non-monetary and non-functional aspects as environmental impact of the vehicle, during its entire lifecycle: production, use and disposal. Multiple studies have contributed to this domain (Delucchi et al., 1989; Lipman and Delucchi, 2006; Hawkins et al., 2012), often referred to as lifecycle analysis. However, while focusing on the full vehicle lifecycle, such approaches are less relevant for modeling individual preferences for vehicle purchase that is usually limited to a timeframe of vehicle use (which is about 5 years in the Netherlands).

Generalized costs are a known concept in transport economics and are commonly used in transportation studies for example in congestion modeling (Small and Verhoef, 2007). This approach recognizes that travelling costs include monetary as well as non-monetary costs. For example generalized travel costs may consist of fuel consumption and maintenance, as well as costs of scheduling and time costs associated with travelling (free-flow travel time and travel delays). While fitting to account for both monetary and non-monetary costs, the concept of generalized costs is not often used for analyzing consumer preferences. We propose hence that GCO form an appropriate framework to account for the various types of costs within a certain time frame of vehicle ownership and use and therefore are directly applicable to the stated preference studies. In the next Section we shall return to this concept when presenting our choice model.

\section{The Model}

A model presented in this paper accounts for the multiple dynamics in the adoption process by distinguishing consumer segments and exploring within-segment preference heterogeneity, the product dynamics as improvements in vehicle characteristics, and the market dynamics in terms of EV visibility, as well as evolution of price and performance of other vehicles on the market.

\subsection{Experimental design (SP)}

To elicit consumer preferences and market dynamics that are not observable at present but are expected to take place in the future, we designed a stated preference experiment in a manner that captures market dynamics during the process of innovation diffusion. On the one hand, it distinguishes different consumer types; on the other hand it also captures the expected development of the innovative product.

The experiment described a situation familiar to respondents: purchase of a vehicle. Respondents were asked to assume that a decision about the make and the brand of the car has already been taken. The remaining decision thus involved the choice between various types of engine that a vehicle may have: an internal 
combustion engine driven on gasoline; a hybrid engine and a full electric engine. All vehicle attributes except for those shown on the choice card were asked to be assumed the same for all types of vehicles. Vehicle options in each choice card were described by ten attributes: purchasing price, expected resale price in 5 years, average costs of gasoline / charging per $100 \mathrm{~km}$; maximum range; minimum range; average CO2 emissions; possibility for a tow hitch; and for the EV option - time needed to charge the vehicle from the socket (at home or work - 'slow charging'), charging time at a rapid charging facility, and time of detour that is needed to arrive at a fast charging facility compared to average travel time to a conventional fuel gas station. For the precise description of choice situation and the attributes, please see Table 1 and Appendix A.

In this study, for the fractional factorial design we apply a balanced orthogonal main-effect plan with 72 choice sets. This plan also included a blocking variable with twelve levels (twelve blocks of six choice sets). The attribute levels were selected in order to cover the scope of interest and were further tuned to allow for efficient identification of model coefficients using simulations.

\subsection{Dynamics of Adoption: Consumer Segments and Market Developments}

Following the theory of diffusion of innovation, different consumers enter the market (i.e. purchase a new product) at different stages. In the beginning of the survey, we have asked respondents to answer a number of questions that helped us divide them in five consumer segments as described in Section 2. A question where respondents were asked to self-select the type of customer they are as car buyers (relevant survey questions are found in part B of the Appendix) was the anchor question which determined to which of the segments each respondents belongs. Next, we used two psychological constructs of general innovativeness and knowledge about alternative vehicle technologies to verify segment membership. More detail on the data and analysis concerning the division of consumer segments is found in Section 5 .

Following Rogers, we assume that the product (an EV) that is being introduced to the market undergoes development during the cycle of diffusion, which implies that vehicle attributes improve as the diffusion process progresses. In order to keep the design compact and to ensure the sufficiency or responses at each stage, we have chosen to distinguish three market conditions: introductory, growth and maturity (their specifications are found below). To incorporate temporal dynamics in consumer heterogeneity, respondents identified as various types of consumers / vehicle buyers were fitted to the corresponding market conditions. Consumers in both Innovators and Early Adopter segments are triggered by the novelty of the product and are taking risks connected to it even in the face of technical inferiority to other options available on the market; they were assigned to the introductory phase. Consumers in the Early Majority segment are more pragmatic, but wish to follow Early Adopters in marking the transition to the novel product, when it improves its characteristics and becomes cheaper due to emerging economies of scale. Respondents identified as Early Majority were assigned to the growth phase. Finally, consumers in the Late Majority segment and Traditionalists are skeptical about novelties and choose to wait and perhaps buy a product at a later stage when it has been tried out, improved its characteristics and to 
fully profit from the economies of scale. These respondents were assigned to the maturity phase of adoption.

The three market conditions vehicle attribute values (see Table A1 in Appendix $D$ for the attribute levels used in the design). In the introduction stage the three vehicles approximately reflect the current situation on the market, where the conventional fuel car is the cheapest in terms of purchasing price, and the electric vehicle the most expensive. Purchasing price was customized according to the intended price respondents were expecting to pay for a next vehicle. Resale price in 5 years - the average vehicle possession time in the Netherlands - was also customized as a proportion of the purchasing price. Operational costs for the vehicles were reversed relative to the purchasing price: full electric vehicle was the cheapest, followed by a hybrid vehicle, and the gasoline vehicle as the most expensive per driven kilometer. An electric vehicle at the introductory stage has a relatively low range, relatively long charging times and long detour times. At the introductory phase of diffusion it was also assumed that due to their low towing potential, it is not possible for a hybrid and a full electric vehicle to install a tow hitch, while a gasoline vehicle does have such an option. ${ }^{2}$

In the two following phases of diffusion, growth and maturity, we assumed that electric vehicles improve their technical characteristics (see Tables A1 and A2). Electric vehicle would improve its driving range and the charging performance. Also, charging infrastructure is assumed to be better developed leading to lower detour times. Besides, due to technology spillovers (Cowan and Hulten, 2006), hybrid and conventional vehicles become more fuel efficient as well, which translates into lower operational costs for these types of vehicles.

\subsection{Generalized Cost of Ownership and Use: an Application}

Each choice set in the experiment as described in Section 3, included 10 choice attributes that were shown to the respondents (see Table 1). The choice attributes make part of monetary as well non-monetary components of the total costs of ownership concept. Pilot testing that included filling out of the survey at the presence of the interviewer and that was followed by an in-depth interview has revealed a particular heuristic related to attribute attendance. During the pilot stage of the survey it became apparent that respondents were not considering each of the 10 shown attributes one by one when making 6 sequential choices, but were clustering the attributes. So, respondents were using the shown attributes to calculate costs and benefits associated with vehicle ownership, in conformity with the GCO principle, broadly defined as:

1. Generalized monetary costs, GMC. These were calculated as a sum of depreciation of vehicle's value in 5 years and operational costs in 5 year time (we note that

\footnotetext{
${ }^{2}$ During the pilot it became apparent that some respondents were having trouble making a choice between the different types of vehicles without having information about the towing potential which is mostly used for towing a caravan. To avoid situations when respondents are forced to make their own assumptions about the availability of a tow hitch, this attribute was explicitly included in the experiment (literally: "Possibility of attaching a tow hitch"). There are about 475,000 caravans in the Netherlands, or about 59 per 1,000 passenger vehicles, the highest caravan density in Europe (BOVAG, 2012).
} 
each card included information on such costs based on the expected number of kilometers driven per year that was indicated by a respondent prior to the choice experiment). ${ }^{3}$

2. Generalized time costs, GTC. Respondents were considering how frequently they'd be using slow or fast charging facilities (a corresponding question about such expected frequencies was included in the survey), and how much time that would take.

3. Generalized environmental costs. Respondents were considering how much of environmental burden in terms of $\mathrm{CO} 2$ emissions they would cause provided the expected yearly mileage.

4. Extra facilities. A possibility of attaching a tow hitch.

TABLE1. Choice experiment attributes.

\begin{tabular}{|c|c|c|}
\hline Attribute & $\begin{array}{c}\text { Type } \\
\text { attribute }\end{array}$ & Description \\
\hline X Purch.Price & generic & $\begin{array}{l}\text { The purchasing price of a vehicle including all taxes but excluding the exchange } \\
\text { value. }\end{array}$ \\
\hline $\mathbf{X}_{\text {Resale }}$ & generic & Expected value of the vehicle at resale in 5 years. \\
\hline $\mathbf{X}_{\text {Opcosts }}$ & generic & $\begin{array}{l}\text { Average costs of gasoline or electricity (for electric vehicle) per } 100 \mathrm{~km} \text { under } \\
\text { normal circumstances. }\end{array}$ \\
\hline$X_{\text {MaxRange }}$ & generic & $\begin{array}{l}\text { Maximum number of } \mathrm{km} \text { that a car can drive with a full tank or a fully charged } \\
\text { battery (for electric vehicle) under normal circumstances }\end{array}$ \\
\hline $\mathbf{X}_{\text {MinRange }}$ & generic & $\begin{array}{l}\text { Maximum number of km that a car can drive with a full tank or a fully charged } \\
\text { battery (for electric vehicle) under unfavorable circumstances. For example, it } \\
\text { may include strong crosswind, uphill driving, extremely hot or cold weather } \\
\text { when substantial motor energy is used for warming up or cooling down the } \\
\text { vehicle. }\end{array}$ \\
\hline $\mathbf{X}_{\text {SlowCh100 }}$ & EV & $\begin{array}{l}\text { (slow charging, per } 100 \mathrm{~km} \text { ) time that is necessary to charge the battery of a fully } \\
\text { electric vehicle from the socket. It takes time (several hours), but may take place } \\
\text { at the moments when the car is not being driven. }\end{array}$ \\
\hline$X_{\text {StCharge }}$ & EV & $\begin{array}{l}\text { (fast charging) time that is necessary to charge the battery of a fully electric } \\
\text { vehicle at a special charging point. It is fast, but some detour is necessary to get } \\
\text { to such charging facility. }\end{array}$ \\
\hline $\mathbf{X}_{\text {Detour }}$ & EV & $\begin{array}{l}\text { Because not all tank stations have fast charging points for electric vehicles, it is } \\
\text { possible that you would need to travel further than you are used to in order to } \\
\text { make use of a fast charging facility. The times provided (in minutes) are above } \\
\text { the time that you normally spend to tank a gasoline vehicle. }\end{array}$ \\
\hline $\mathrm{X}_{\mathrm{CO} 2 \mathrm{~km}}$ & generic & $\begin{array}{l}\text { Official average emission of } \mathrm{CO} 2 \text { per each } \mathrm{km} \text { driven under normal } \\
\text { circumstances (producer specifications). }\end{array}$ \\
\hline $\mathbf{X}_{\mathrm{TH}}$ & generic & possibility for a tow hitch (binary). \\
\hline
\end{tabular}

\footnotetext{
${ }^{3}$ To keep the experiment doable for the respondents, not all monetary components were included. We limited the number of monetary attributes to three (purchasing price, resale price and operational costs), while other costs were said to be assumed the same across all alternatives.

${ }^{4}$ In the description of a full electric vehicle preceding the choice experiment, it was mentioned that such a vehicle produces no direct tailpipe emissions of $\mathrm{CO} 2$ or particulate matter.
} 
In our case, GCO can be defined as GCO $=\mathrm{GMC}+\alpha_{\text {time }} * \mathrm{GTC}+\alpha_{\mathrm{CO} 2} * \mathrm{GEC}$, where $\alpha_{\text {time }}$ denotes a value of time and $\alpha_{\mathrm{CO} 2}$ denotes a value of $\mathrm{CO} 2$ emissions.

Variables corresponding to the GCO concept should be computed from the choice attributes and additional variables available from the questionnaire. The following elements of the total cost of ownership are constructed:

a) Generalised yearly monetary costs (GMC, euros per year) associated with vehicle possession and use. GMC include depreciation of the car in the period of 5 years and yearly operational costs and are obtained as follows:

$\mathrm{X}_{\mathrm{GMC}}=\left(\left[\mathrm{X}_{\text {Purch.Price }}-\mathrm{X}_{\text {PVResale }}\right] \div 5\right)+\left(\left[\mathrm{X}_{\text {OpCosts }} / 100\right] * \mathrm{X}_{\mathrm{Km}}\right)$

where:

$\mathrm{X}_{\text {PVResale }}=\mathrm{X}_{\text {Resale }} /(1+r)^{\mathrm{t}}$

and

$\mathrm{X}_{\mathrm{PVResale}}$ - present value of the repurchasing price in 5 years assuming a discount rate $r$ of $5 \%$ per year;

$\mathrm{X}_{\text {Purch.Price }}, \mathrm{X}_{\text {Resale }}, \mathrm{X}_{\mathrm{Op} . \text { Costs }}$ are choice attributes;

$\mathrm{X}_{\mathrm{Km}}$ - expected yearly mileage. It was asked before the choice experiment as a number of kilometers per year that respondents were expecting to drive in their next car (see Appendix part C).

b) Generalised yearly time costs spent on fast charging ( $\mathrm{GTC}_{\mathrm{FC}}$, hours per year). It includes the time for detour in excess of the average time spent to reach a gasoline station and the time spent on fast charging itself and is calculated as follows:

$\mathrm{X}_{\mathrm{GTC} \_ \text {FastCh }}=\left(\left[\mathrm{X}_{\text {FastCharge }}+\mathrm{x}_{\text {Detour }}\right] / 60\right) *\left(\mathrm{X}_{\mathrm{Km}} / \mathrm{x}_{\text {MinRange }}\right) * \mathrm{P}_{\text {FastCh }}$

where:

$\mathrm{X}_{\text {FastCh }}, \mathrm{X}_{\text {Detour }}, \mathrm{X}_{\text {MinRange }}$ are choice attributes;

$\mathrm{X}_{\mathrm{Km}}$ - expected yearly mileage as explained above;

$\mathrm{P}_{\text {Fastch }}$ - the probability that a respondent would expect to use a fast charging facility, asked after the choice experiment (see Appendix part C).

c) Generalised yearly time costs spent on slow charging (GTC $\mathrm{SC}_{\mathrm{SC}}$, hours per year), obtained as follows:

$\mathrm{x}_{\text {GTC_SlowCh }}=\mathrm{x}_{\text {SlowCh100 }} *\left(\mathrm{x}_{\text {MaxRange }} / 100\right) *\left(\mathrm{x}_{\mathrm{Km}} / \mathrm{x}_{\text {MinRange }}\right) * \mathrm{P}_{\text {SlowCh }}$

where:

$\mathrm{X}_{\text {SlowCh100 }}, \mathrm{X}_{\text {MaxRange }}$ and $\mathrm{X}_{\text {MinRange }}$ are choice attributes;

$\mathrm{X}_{\mathrm{Km}}$ - expected yearly mileage as explained above;

$P_{\text {Slowch }}$ - the probability that a respondent would expect to use a slow charging facility, asked after the choice experiment and is equal to [1- $\left.P_{\text {Fastch }}\right]$ (see Appendix part C).

d) Generalised yearly environmental costs of $\mathrm{CO} 2$ emissions in tons exhausted by a vehicle during a year $\left(\mathrm{GEC}_{\mathrm{CO} 2}, \mathrm{t} / \mathrm{year}\right)$, calculated as follows: 
$\mathrm{x}_{\mathrm{GEC} \_\mathrm{CO} 2}=\mathrm{x}_{\mathrm{CO} 2} * \mathrm{x}_{\mathrm{Km}} / 1,000,000$

where:

$\mathrm{X}_{\mathrm{CO} 2}$ is a CE attribute;

$\mathrm{X}_{\mathrm{Km}}$ - expected number of kilometers driven per year, as explained above.

\section{Model Estimation}

\subsection{Nested Logit Model}

A standard discrete choice model that assumes that respondent's m utility of alternative $i$ is defined as (Louviere, Hensher and Swait, 2000):

$\mathrm{U}_{\mathrm{im}}=\mathrm{V}_{\mathrm{im}}+\varepsilon_{\mathrm{im}}$

Where $V_{i m}$ part is a systematic component of the $i^{\text {th }}$ alternative to the $\mathrm{m}^{\text {th }}$ individual that represents part of the utility that is contributed by attributes of each alternative included in a stated choice experiment; this part is observable to the analyst. $V_{\text {im }}$ is defined as

$$
V_{\text {im }}=\Sigma_{n=1}^{N}\left(\beta_{\text {in }} X_{\text {inm }}\right)
$$

where $\beta^{\prime}$ s are utility parameters and $x^{\prime}$ s are attributes $(n=1 \ldots N)$ of the alternatives. $\varepsilon_{\text {im }}$ is a random component that reflects part of utility that is contributed by unobserved attributes depending on individual preferences, which accounts for all other properties of alternatives important to the individual but not included in the experiment. If some alternatives are more similar to each other in unobserved characteristics, correlations in the error terms between alternatives are suspected so that cross-substitutions between pairs of alternatives may not be equal but are affected by the presence of other alternatives. This means that iid assumption behind the random utility model cannot hold, and a generalized extreme value (GEV) model would be more appropriate. In GEV model, the iid assumption is partially relaxed so that random components are allowed to correlate within a choice set but not across the choice sets, which allows to accommodate differential degrees of similarity between the alternatives within the same nest. The probability $P_{m i}$ within a nested structure that a particular option is chosen can be expressed following Train (2003):

$$
P_{m i}=\left[e^{V m i} / \lambda k\left(\Sigma_{j € q k} e^{V m j / \lambda k}\right)^{\lambda k-1}\right] /\left[\Sigma_{1 \ldots 1 . . . k}\left(\Sigma_{j € q l} e^{V m j / \lambda l}\right)^{\lambda l}\right]
$$

Where $\lambda$ is a measure of correlation in unobserved factors within the nest. In order to identify which variables have an effect on individual choices, we need to estimate parameters $\beta$ 's from equation [2], which is done by means of maximum likelihood estimation. We used BIOGEME open source software to estimate the model (Bierlaire 2003 and Bierlaire 2008).

\subsection{Utility Specification}

Our experiment includes three alternatives, a vehicle with a full electric motor, with a hybrid motor and with a conventional gasoline motor. We expect that the alternatives of vehicles with a hybrid motor and a conventional gasoline motor are similar to each other in unobserved factors that might be related to 'business-asusual' vehicle characteristics. These are opposed to a full electric vehicle that is an 
innovative product, requires new skills and new behavioral patterns related to charging. A two-level nested structure suits the purposes of this experiment where we assume that one nest is formed by a vehicle with an electric motor; and the other nest by vehicles with a hybrid and conventional motors. Utility functions that are associated with each alternative can be expressed as consisting of monetary and nonmonetary costs related to vehicle ownership [6-10]:

$$
\begin{aligned}
& \mathrm{U}_{\mathrm{EV}}=\mathrm{ASC}_{\mathrm{EV}}+\beta_{\mathrm{GMC}} * \mathrm{x}_{\mathrm{GMC}}+\beta_{\mathrm{GTC} \_\mathrm{FC}} * \mathrm{x}_{\mathrm{GTC} \text { FastCh }}+\beta_{\mathrm{GTC}} \mathrm{SC} * \mathrm{x}_{\mathrm{GTC} \text { SllowCh }} \\
& +\beta_{T H} * x_{T H} \\
& U_{H}=\lambda *\left(A_{S C} C_{H}+\beta_{G M C} * x_{G M C}+\beta_{T H} * x_{T H}+\beta_{G_{G E C} C O 2} * x_{G_{E E C} C O 2}\right) \\
& \mathrm{U}_{\mathrm{CV}}=\lambda *\left(\beta_{\mathrm{GMC}} * \mathrm{x}_{\mathrm{GMC}}+\beta_{\mathrm{TH}} * 1+\beta_{\mathrm{GEC}} \mathrm{CO} 2 * \mathrm{x}_{\mathrm{GEC} \_\mathrm{CO} 2}\right)
\end{aligned}
$$

Where:

$\mathrm{ASC}_{\mathrm{EV}}$ - alternative specific constant for the option of full electric motor;

$\mathrm{ASC}_{\mathrm{H}}$ - alternative specific constant for the option of a hybrid motor;

$\mathrm{X}_{\mathrm{GMC}}, \mathrm{X}_{\mathrm{FastCh}}, \mathrm{X}_{\mathrm{SlowCh}}, \mathrm{X}_{\mathrm{CO} 2}$ and $\mathrm{X}_{\mathrm{TH}}$ are variables and attributes as described above;

$\beta_{\mathrm{GMC}} \beta_{\mathrm{FastCh}}, \beta_{\text {SlowCh, }} \beta_{\mathrm{CO} 2,} \beta_{\mathrm{TH}}-$ are corresponding coefficients estimated in a nested model;

$\lambda$ - a measure of correlation in unobserved factors within the nest (here: hybrid, conventional).

Once the monetary parameter, $\beta_{\mathrm{GMC}}$, is known, one can obtain implicit valuations of willingness to pay or accept (Louviere, Hensher and Swait, 2000). Valuations of the full electric and hybrid motor alternatives relative to the conventional vehicle ${ }^{5}$ can be obtained by dividing the alternative specific constants by the monetary attribute parameter: $\mathrm{ASC}_{\mathrm{EV}} / \beta_{\mathrm{GMC}}$ and $\mathrm{ASC}_{\mathrm{H}} / \beta_{\mathrm{GMC}}$. Next, four willingness to pay indicators, WTP, can be obtained (see also Small and Verhoef, 2007):

- value of time associated with fast charging: $\alpha_{\text {time_FastCh }}=\beta_{\text {GTC_FC }} / \beta_{\text {GMC; }}$

- value of time associated with slow charging: $\alpha_{\text {time_SlowCh }}=\beta_{\text {GTC_SC }} / \beta_{G M C}$;

- Value of $\mathrm{CO} 2$ emissions: $\alpha_{\mathrm{CO2}}=\beta_{\mathrm{GEC}} \mathrm{CO} / \beta_{\mathrm{GMC}}$;

- value of a possibility for tow hitch facility: $\beta_{\mathrm{TH}} / \beta_{\mathrm{GMC}}$.

\section{The Data}

The data was collected during June 2012 in a large-scale internet survey using an internet panel of a commercial marketing research company (Panel Inzicht). The survey was on average $30 \mathrm{~min}$ long and was filled in by 2,977 respondents (valid responses). The sample is fairly representative of general Dutch adult population and of driver license holders in terms of age, gender, education and income (statistics found in Table 2). The questionnaire included questions on the stated and revealed preferences and besides the stated choice experiment, included questions on current

\footnotetext{
${ }^{5}$ Our choice of leaving a conventional vehicle as a reference choice stems from the 'embeddedness' of preferences such that a new product on the market being explicitly compared to the existing product (Struben \& Sterman 2008; Cowan \& Hulten 1996; Woerdman 2004).
} 
vehicle possession, vehicle characteristics, travelling pattern, expected next car (replacing one of the household cars or as an extra car), as well as questions asking for attitudes towards full electric vehicles, and perception of EV and CV functional and non-functional characteristics. Questions that are relevant for the current study are found in the Appendix part B. The entire survey is available from the authors upon request.

TABLE 2. Sample statistics.

\begin{tabular}{|c|c|c|c|}
\hline & Car owners (\%) ${ }^{\mathrm{a}}$ & Dutch population & Whole sample \\
\hline Gender (male) & n.a. & $49.5 \%$ & $49.6 \%$ \\
\hline \multicolumn{4}{|l|}{ Age $^{\mathrm{c}}$} \\
\hline $19-25$ & $6.7 \%$ & $8.1 \%$ & $6.4 \%$ \\
\hline $26-35$ & $15.0 \%$ & $15.7 \%$ & $15.6 \%$ \\
\hline $36-45$ & $21.5 \%$ & $19.0 \%$ & $25.9 \%$ \\
\hline $46-55$ & $22.9 \%$ & $19.6 \%$ & $22.3 \%$ \\
\hline $56-65$ & $18.4 \%$ & $17.2 \%$ & $15.9 \%$ \\
\hline 65 and older & $15.5 \%$ & $20.4 \%$ & $14.0 \%$ \\
\hline \multicolumn{4}{|l|}{ Education } \\
\hline primary or lower & n.a. & $5.1 \%$ & $8.1 \%$ \\
\hline secondary and vocational & n.a. & $60.3 \%$ & $56.6 \%$ \\
\hline college and university & n.a. & $33.6 \%$ & $35.3 \%$ \\
\hline \multicolumn{4}{|l|}{ Household income $^{\mathrm{d}}$} \\
\hline below $€ 15,900$ & n.a. & $20 \%$ & $9.9 \%$ \\
\hline$€ 15,900-€ 22,400$ & n.a. & $20 \%$ & $14.9 \%$ \\
\hline$€ 22,400-€ 30,400$ & n.a. & $20 \%$ & $17.4 \%$ \\
\hline$€ 30,400-€ 41,000$ & n.a. & $10 \%$ & $11.0 \%$ \\
\hline$€ 41,000-€ 51,000$ & n.a. & $20 \%$ & $14.6 \%$ \\
\hline above $€ 51,000$ & n.a. & $10 \%$ & $7.3 \%$ \\
\hline unknown & n.a. & --- & $24.9 \%$ \\
\hline
\end{tabular}

${ }^{a}$ Source: BOVAG-RAI (2012)

${ }^{b}$ Source: Statistics Netherlands (CBS, 2011)

${ }^{c}$ Data for the Dutch population (Statistics Netherlands, 2011) is provided for the population of age 20 and older.

${ }^{d}$ Data on income is available from Statistics Netherlands (CBS, 2011) for disposable household income deciles (appear in the Table). Our data was gathered for household gross income using the following breakdown: below $€ 15,000 ; € 15,001$ - €20,000; €20,001 - €25,000; €25,001-€30,000; €30,001 - €40,000; $€ 40,001$ - €50,000; €50,001 - €60,000; €60,001 - €70,000; €70,001 - €95,000; above €95,001.

We have distinguished 5 groups of respondents following the consumer segments described by the diffusion theory outlined in Section 2. Three questions were used. As a first step, respondents were asked to provide their opinion on 12 statements concerning their general innovativeness, i.e. their attitude towards innovative products in general in terms of possession, purchase and use. The items reflected hedonic, social/symbolic and informational aspects of innovativeness (Vandecasteele and Geuens 2010, Jager 2009). After that, a question was asked about knowledge respondents had about the alternative vehicle technology (consisting of 3 items). Both scales were thoroughly pre-tested; factor analysis has shown high consistency for both constructs (respective Cronbach's alphas are: $\alpha_{\text {innov }}=.932$ and $\alpha_{\text {know }}=.912$ ). Finally, respondents were asked to make a choice between five descriptions of the type of consumer regarding the purchase of an innovative vehicle. 
As a result the last question was a decisive one in determining to which of the ideal consumer types each respondent belongs. In this sample of 2977 respondents, 10\% fell in the segment Innovators and Early Adopters; $42 \%$ of respondents were identified as Early Majority; $38 \%$ were classified as the Late Majority; and the last $10 \%$ found themselves among the Traditionalists. These groups were then validated based on their psycho-demographic characteristics. The first propositions that follow from the diffusion theory concern the general innovativeness and knowledge. Group mean scores for these indicators (found in Table 3) smoothly decrease as we proceed from the earlier adopters to the later adopters, and are statistically different between all of the identified segments.

Connected to the knowledge concept is education: theory proposes that earlier adopters have more years of formal education than do later adopters. Our data shows that respondents in late majority and traditionalist segments have lower average education level than earlier adopters and differ from them in statistical terms. Finally, while the theory does not have specific propositions concerning the relationship between adoption of innovation and age or gender, in our case average age of respondents increases with each following adopter group where again late majority and traditionalists differ statistically from all other consumer segments. The biggest proportion of males is among the innovator and the early adopter groups than in any other segments, which is basically a pretty intuitive result for our case of vehicle adoption.

Details on the design of the stated preference study can be found in the Appendix part A. Recall that in order to account for market dynamics in product development (shifts in the performance of the electrical vehicle in the course of a long run adoption process) cards varied in attribute value levels according to the stages (see Appendix D, Tables A1 and A2). Furthermore, to account for consumer dynamics described in section 3 , depending on the specific adopter segment that a respondent has assigned his/herself to (innovator, early adopter; early majority; late majority or traditionalist), respondents were shown cards with attribute levels appropriate for their stage.

TABLE 3. Demographic and psychological profile of the sample and per consumer segment (standard deviation in parentheses).

\begin{tabular}{|c|c|c|c|c|c|}
\hline & $\begin{array}{l}\text { INNOVATORS } \\
\text { and EARLY } \\
\text { ADOPTERS }\end{array}$ & $\begin{array}{l}\text { EARLY } \\
\text { MAJORITY }\end{array}$ & LATE MAJORITY & $\begin{array}{l}\text { TRADITIO- } \\
\text { NALISTS }\end{array}$ & Sample Total \\
\hline $\begin{array}{r}\text { Average innovative- } \\
\text { ness score }\end{array}$ & $\begin{array}{r}* 3.61 \\
(0.91) \\
\end{array}$ & $\begin{array}{r}* 2.62 \\
(0.88) \\
\end{array}$ & $\begin{array}{r}* 2.03 \\
(0.77) \\
\end{array}$ & $\begin{array}{r}* * 1.87 \\
(0.74) \\
\end{array}$ & $\begin{array}{r}2.42 \\
(0.96) \\
\end{array}$ \\
\hline $\begin{array}{r}\text { Average knowledge } \\
\text { score }^{\text {b }}\end{array}$ & $\begin{array}{r}* 4.08 \\
(1.06) \\
\end{array}$ & $\begin{array}{r}* 3.22 \\
(1.18)\end{array}$ & $\begin{array}{r}* * 2.63 \\
(1.23)\end{array}$ & $\begin{array}{r}* * 2.20 \\
(1.24)\end{array}$ & $\begin{array}{r}2.98 \\
(1.29) \\
\end{array}$ \\
\hline Education $^{c}$ & $\begin{array}{r}4.97 \\
(1.32)\end{array}$ & $\begin{array}{r}4.94 \\
(1.34)\end{array}$ & $\begin{array}{r}* * 4.40 \\
(1.42)\end{array}$ & $\begin{array}{r}* * 3.93 \\
(1.43)\end{array}$ & $\begin{array}{r}4.64 \\
(1.42)\end{array}$ \\
\hline Age & $\begin{array}{r}43.89 \\
(14.36) \\
\end{array}$ & $\begin{array}{r}46.25 \\
(13.85) \\
\end{array}$ & $\begin{array}{r}* 48.49 \\
(13.79) \\
\end{array}$ & $\begin{array}{r}* 52.12 \\
(13.84) \\
\end{array}$ & $\begin{array}{r}47.45 \\
(14.03) \\
\end{array}$ \\
\hline Males & $\begin{array}{r}* * 0.687 \\
(0.46) \\
\end{array}$ & $\begin{array}{l}0.512 \\
(0.50)\end{array}$ & $\begin{array}{l}0.433 \\
(0.49)\end{array}$ & $\begin{array}{l}0.476 \\
(0.50)\end{array}$ & $\begin{array}{l}0.496 \\
(0.50)\end{array}$ \\
\hline N resp. & 294 & 1256 & 1132 & 292 & 2974 \\
\hline$\%$ of the sample & $9.89 \%$ & $42.23 \%$ & $38.06 \%$ & $9.82 \%$ & $100.00 \%$ \\
\hline
\end{tabular}

\footnotetext{
** statistically different from all other sub-groups at $5 \%$ level.
} 
${ }^{a}$ Average innovativeness is an average score of 12 items measuring general innovativeness with respect to consumer goods (see Appendix B).

${ }^{\mathrm{b}}$ Average knowledge is an average score of 3 items measuring individual knowledge about alternative vehicle technology (see Appendix B).

${ }^{\mathrm{C}}$ Education is measured by asking to indicate the highest achieved level of education using the following categories: 1 - elementary school; 2 - lower vocational education (LBO, LEAO, LHNO, LTS); 3 secondary education (MAVO, VMBO, MULO); 4 - vocational secondary education (MBO); 5 - high school (HAVO, HBS, VWO); 6 - college (HBO, HTS, HEAO); 7 - university education.

\section{Results}

We estimated nested logit models with utilities based on the total-cost-of-ownership approach, and specified following the description in section 4. Estimated model for the entire sample is found in Table 4 (model 1). All estimated utility parameters are significant and have plausible signs. All costs parameters are negative reflecting disutility associated with monetary costs, slow and fast charging time costs and environmental costs. The alternative specific constant of the full electric vehicle alternative is negative which shows that respondents on average consider an EV as less favorable in comparison to a conventional fuel vehicle. On average, a hybrid vehicle is preferred to a conventional vehicle (positive ASC hybrid).

Valuations obtained from the estimated parameters are found in Table 5. For Dutch drivers in general (pooled model), the point estimate for a full electric vehicle valuation is negative at $€ 1,984$ per year, while the point estimate for a hybrid vehicle valuation is positive at $€ 907$ per year. This implies that on average, given current experimental setting, respondents are willing to be compensated for possession of an EV and are willing to pay additional amount of money for the possession of a hybrid vehicle, both in comparison to a conventional vehicle. These figures seen as yearly tax reliefs for the use of EVs and higher burdens for the use of hybrid vehicles can be interpreted as $€ 165$ monthly compensation per full electric vehicle; which is about two times the amount that an average diesel vehicle owner pays for the road tax (Belastingdienst, 2012).

Costs associated with fast charging are estimated at -€63 per hour which is substantially higher, about a factor 10, than the value of time (VOT) estimates obtained in other contexts (see Knockaert et al. 2012, Bockarjova et al. 2012). This points at extreme inconvenience that respondents attach to time spent on fast charging when they are on route for long distance trips, given the expected frequency of charging for electric vehicle. (Average expected frequency of fast charging in our sample is $31 \%$, and average mileage per year is $15,000 \mathrm{~km}$; this means that average yearly time costs spent on rapid charging per electric vehicle are expectedly 10.5 h/year).

The point estimate of time spent on slow charging is valued at -€0.94 per hour, and does not reflect waiting time as such but a slight scheduling inconvenience. Charging time is not 'wasted' as slow charging usually takes place at the moments when the car is normally not used like at night or during working hours. The disadvantage of a long charging time is a lack of flexibility because the car cannot be used when there is a sudden change in plans. 
TABLE 4. Nested logit estimations of TCO model per consumer segment (standard errors in parentheses).

\begin{tabular}{|c|c|c|c|c|c|}
\hline & Pooled & $\begin{array}{l}\text { Innovators and } \\
\text { Early Adopters }\end{array}$ & Early Majority & Late Majority & Traditionalists \\
\hline & 1 & 2 & 3 & 4 & 4 \\
\hline ASC (EV) & $\begin{array}{r}-0.6199^{* * *} \\
(0.0513)\end{array}$ & $\begin{array}{ll}-0.664 & * * \\
(0.274) & \end{array}$ & $\begin{array}{l}-0.341^{* * *} \\
(0.101)\end{array}$ & $\begin{array}{rl}-0.465 & * * * \\
(0.0787) & \end{array}$ & $\begin{array}{l}-0.8122^{* * *} \\
(0.184)\end{array}$ \\
\hline ASC (Hybrid) & $\begin{array}{r}0.283^{* * *} \\
(0.0287)\end{array}$ & $\begin{array}{r}0.407 \text { ** } \\
(0.157)\end{array}$ & $\begin{array}{r}0.553 \\
(0.0696)\end{array}$ & $\begin{array}{r}0.234 \\
(0.0389)\end{array}$ & $\begin{array}{l}-0.0597 \\
(0.0599)\end{array}$ \\
\hline Gen.Mon.Costs $(€ / y)$ & $\begin{array}{rl}-0.00031 & * * * \\
(0.00003) & \end{array}$ & $\begin{array}{rl}-0.00026 & * * * \\
(0.00008) & \end{array}$ & $\begin{array}{r}-0.00038 \quad * * * \\
(0.00004)\end{array}$ & 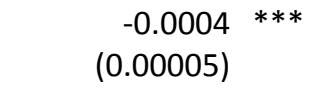 & $\begin{array}{rl}-0.0003 & * * * \\
(0.0001) & \end{array}$ \\
\hline Costs st.charge $(\mathrm{h} / \mathrm{y})$ & $\begin{array}{r}-0.0198 * * * \\
(0.00125)\end{array}$ & $\begin{array}{r}-0.0124 * * * \\
(0.00212)\end{array}$ & $\begin{array}{r}-0.0208 * * * \\
(0.00189)\end{array}$ & $\begin{array}{r}-0.0344 * * * \\
(0.00363)\end{array}$ & $\begin{array}{r}-0.036 \text { *** } \\
(0.00847)\end{array}$ \\
\hline Costs slow charge $(\mathrm{h} / \mathrm{y})$ & $\begin{array}{r}-0.00029 * * * \\
(0.00006)\end{array}$ & $\begin{array}{r}-0.00007 \\
(0.00016)\end{array}$ & $\begin{array}{r}-0.00014 \\
(0.00009)\end{array}$ & $\begin{array}{rl}-0.00067 & * * * \\
(0.00012) & \end{array}$ & $\begin{array}{r}-0.00044 \\
(0.00024)\end{array}$ \\
\hline Costs $\operatorname{CO} 2(t / y)$ & $\begin{array}{r}-0.0502 \\
(0.00896)\end{array}$ & $\begin{array}{r}-0.00856 \\
(0.02480)\end{array}$ & $\begin{array}{r}0.0145 \\
(0.0138)\end{array}$ & $\begin{array}{c}-0.0388 \quad * * \\
(0.0187)\end{array}$ & $\begin{array}{r}-0.0492 \\
(0.0387)\end{array}$ \\
\hline Tow hitch & $\begin{array}{r}0.1688^{* * *} \\
(0.0194)\end{array}$ & --- & $\begin{array}{l}0.177^{* * *} \\
(0.0292)\end{array}$ & $\begin{array}{r}0.219 \text { *** } \\
(0.033)\end{array}$ & $\begin{array}{r}0.170 \\
(0.0735)\end{array}$ \\
\hline $\mathrm{MU}(\mathrm{H}, \mathrm{ICE})$ & $1^{1.84} 4^{* * *}$ & $\begin{array}{r}1.40 \\
(0.474)^{* * *}\end{array}$ & ${ }^{1.81}{ }^{* * *}$ & $\begin{array}{l}1.666^{* * *} \\
(0.212)\end{array}$ & $\begin{array}{l}1.46 \\
(0.543)\end{array}$ \\
\hline$N$ of parameters: & 8 & 7 & 8 & 8 & 8 \\
\hline Sample size: & 17862 & 1770 & 7536 & 6804 & 1752 \\
\hline Final log-likelihood: & -18000 & -1663 & -7306 & -7013 & -1808 \\
\hline Final gradient norm: & 0.015 & 0.0077 & 0.0045 & 0.0127 & 0.0058 \\
\hline
\end{tabular}

*** parameter is statistically significant at least at $1 \%$ level.

** parameter is statistically significant at least at $5 \%$ level. 
TABLE 5. Cost valuations based on nested logit estimates.

\begin{tabular}{|c|c|c|c|c|c|c|}
\hline & Pooled & $\begin{array}{l}\text { Innovators and } \\
\text { Early Adopters }\end{array}$ & Early Majority & Late Majori & rity & Traditionalists \\
\hline EV const. $(€ / y)$ & $\begin{array}{c}-€ 1,984 \\
(232)\end{array}$ & $\begin{array}{r}-€ 2,604 \\
(1,334)\end{array}$ & $\begin{array}{l}-€ 902 * * \\
(286)\end{array}$ & $\begin{array}{r}-€ 1,174 \\
(243)\end{array}$ & $* *$ & $\begin{array}{r}-€ 2,743 * * \\
(1,147)\end{array}$ \\
\hline Hybrid const. $(€ / y)$ & $\begin{array}{l}€ 907 * * \\
(119)\end{array}$ & $\begin{array}{r}€ 1,596 \\
(784)\end{array}$ & $\begin{array}{c}€ 1,463 \\
(246)\end{array}$ & $\begin{array}{l}€ 591 \\
(121)\end{array}$ & $* *$ & $\begin{array}{r}-€ 202 \\
(214)\end{array}$ \\
\hline $\begin{array}{l}\text { VOT Fast charge \& } \\
\text { detour }(€ / h)\end{array}$ & $\begin{array}{c}-€ 63.46 * * \\
(6.59)\end{array}$ & $\begin{array}{l}-€ 48.63 * * \\
(16.96)\end{array}$ & $\begin{array}{c}-€ \mathbf{5 5 . 0 3} \\
(7.93)\end{array}$ & $\begin{array}{r}-€ 86.87 \\
(13.83)\end{array}$ & $* *$ & $\begin{array}{c}-€ 121.62 * * \\
(51.43)\end{array}$ \\
\hline $\begin{array}{l}\text { VOT Slow charge } \\
(€ / \mathrm{h})\end{array}$ & $\begin{array}{r}-€ 0.94 \\
(0.21)\end{array}$ & $\begin{array}{r}-€ 0.27 \\
(0.64)\end{array}$ & $\begin{array}{r}-€ 0.37 \\
(0.24)\end{array}$ & $\begin{array}{r}-€ 1.68 \\
(0.36)\end{array}$ & $* *$ & $\begin{array}{r}-€ 1.48 \\
(0.96)\end{array}$ \\
\hline WTP for CO2 $(€ / t)$ & $\begin{array}{c}€ 1611^{* *} \\
(32)\end{array}$ & $\begin{array}{l}€ \mathbf{3 4} \\
(98)\end{array}$ & $\begin{array}{l}€ \mathbf{3 8} \\
(37)\end{array}$ & $\begin{array}{l}€ 98 \\
(49)\end{array}$ & $* *$ & $\begin{array}{l}€ 166 \\
(143)\end{array}$ \\
\hline $\begin{array}{l}\text { WTP for tow hitch } \\
(€ / y)\end{array}$ & $\begin{array}{l}€ 5388^{* *} \\
(76)\end{array}$ & --- & $\begin{array}{l}€ 4688^{* *} \\
(93)\end{array}$ & $\begin{array}{l}€ 553 * \\
(106)\end{array}$ & $* *$ & $\begin{array}{l}€ 574^{* *} \\
(320)\end{array}$ \\
\hline$N$ respondents & 2977 & 295 & 1256 & 1134 & & 292 \\
\hline N observations & 17862 & 1770 & 7536 & 6804 & & 1752 \\
\hline
\end{tabular}

\# Standard deviations (in the parentheses) are obtained using the delta method.

** Estimates are statistically significant at $5 \%$ level.

The point estimate for $\mathrm{CO}_{2}$ emission reduction is $€ 161$ per ton $\mathrm{CO} 2$ for the whole sample. This figure is substantially higher than current market prices per ton $\mathrm{CO} 2$ that fluctuate around $€ 7$ on the spot market and around $€ 15$ for futures (EEX, 2013). While current $\mathrm{CO}_{2}$ market prices are relatively low presumably due to economic downturn and are expected to rise in the future to the level of $€ 20$ (Reuters, 2013) our estimate is about 10 times the market average.

Finally, the possibility for a vehicle to have a tow hitch is valued at $€ 538$ on a yearly basis; or $€ 2,690$ per 5 years, the implicit time horizon for vehicle possession we used in the survey, consistent with the average duration of vehicle possession in The Netherlands. This estimated WTP is higher than the actual costs of adding a tow hitch to a vehicle (about $€ 1,000-1,500$ ), and shows that the actual cost of a hitch is lower than what the average consumer is prepared to pay for it.

Estimates are robust with respect to the assumed discount rate. Presented valuations are obtained with $r=5 \%$; alternative estimations with $r=2 \%$ and $r=10 \%$ yielded estimates that mostly remained within $2.5 \%$ margin of the WTP values presented here.

\subsection{Consumer segments}

The estimates presented above are essentially average estimates throughout the whole sample. However, as we described in Section 2, adoption of a new product on the market often displays a pattern where different types of consumers enter the market at different points in time. As shown in section 5, these consumers differ in socio-economic characteristics and psychological profiles but presumably also in their preferences for vehicle choice. This distinction is therefore crucial for diffusion strategy and practice, as well as for policy guidance in case government decides to facilitate (or for that matter, 
impede) product adoption. In order to guide policy and practice, we have performed split sample analysis for each of the consumer groups separately (Table 4, models 2 to 5).

The obtained results demonstrate that different attributes determine preference for EVs for the four different consumer segments. So, for respondents found in the late majority segment all variables included in the model are significant in determining their vehicle preferences, and coefficients have expected signs. Respondents identified as early adopters, early majority and late majority associate positive utility with a hybrid vehicle and negative utility with full electric vehicle compared to a conventional fuel vehicle. Next, for all consumers time spent on fast charging yields significantly negative utility; and only for the late majority the time spent on slow charging is statistically significant and has a negative effect on utility. Possibility for a tow hitch provides positive utility for all consumer types where this facility was available for all vehicles (except Innovators and Early Adopters, which reflects current situation on the market). Positive utility associated with $\mathrm{CO} 2$ reductions is only significant in determination of preferences for the late majority segment.

Further it is of interest to consider the cost valuations per consumer category (Table 5). Valuation of hybrid vehicles relative to a gasoline vehicle is positive for all consumer segments except for traditionalists (for them, it is negative but statistically insignificant). The valuation drops gradually (from $€ 1,596$ per year for the early adopters, $€ 1,463$ for the early majority down to $€ 591$ for the late majority). This shows that consumers, already in current situation as modeled in the first phase of this experiment, do not need direct monetary compensation for hybrid possession, but are willing to bear additional monetary costs associated with this vehicle ownership.

While consumers are willing to pay for hybrid possession, valuations of EV ownership are on average negative through all consumer segments. Point estimates for the valuation of an electric vehicle follow an inverse $U$ shape: it is low for the early majority and innovators (-€2,604 per year, but insignificant), rises to -€902 and -€1,174 for the early majority and late majority segments, and drops again for traditionalists ($€ 2,743$ per year). This shows that even in the early introductory phase first adopters (Innovators and Early Adopters segment) do require financial reward for EV possession. For the next adoption stage of growth (early majority), given specified vehicle characteristics, less direct financial support is required; however importantly it points at the need for a long-term use of financial instruments in promoting EV adoption.

At the final stage of adoption when traditionalists enter the market, it seems like direct financial compensation even needs to be increased; but this result has yet to be taken with caution. Traditionalists are the most conservative consumer category, and the best point of reference for this group is the past. The innovation-decision process of traditionalists is relatively lengthy, and they need substantial time to get used to a new product and build confidence in it. At the moment, Traditionalists do not have a "past" yet to refer to, and they are the least familiar with EV technology (Table 3). This may explain why their current overall valuation of EV is the most negative. As the vehicle becomes more visible on the streets, better tested and further developed, traditionalists 
may adjust their attitudes which in turn may make their preferences turn more favourable towards EVs.

Value of time spent on fast charging is negative and increasing in its absolute value throughout the adoption segments: it mounts to - $€ 48$ and $-€ 55$ per hour for the early adopters and early majority segments, respectively; it jumps to - $€ 87$ for the late majority and peaks with - $€ 122$ per hour for traditionalists. These numbers might look overestimated in comparison to VOT estimates from other studies ranging generally between $€ 5$ and $€ 10$ per hour. However, our estimates most probably signal the importance that respondents attach to the presence of high time costs associated with charging events for an EV, given high frequency of charging due to the limited range of the vehicle.

Interestingly enough, Table 5 resembles a single statistically significant point estimate for slow charging of $-€ 1.68$ per hour for the late majority. This number stays below the regular VOT values. Supposedly it reflects two types of costs, a) the scheduling costs associated with performing regular charging routines, and b) the uncertainty costs resulting from the fact that occasionally the vehicle may not be directly available for spontaneous as well as scheduled trips if the battery is not fully loaded.

On the other hand, relatively high VOT estimates for the time spent on rapid charging rather reflect the time spent on each charging event, given the average attribute values (Table A2 in Appendix D). Even though the time needed for fast charging of an EV, and which includes detour, waiting and charging, is decreasing with each following stage (50min in the introductory stage, $35 \mathrm{~min}$ in the mass market phase and $25 \mathrm{~min}$ in the maturity phase), VOT is increasing. This signals that time associated with rapid charging thus appears to be one of the critical impediments on the way to EV adoption, as consumers essentially demand a vehicle on the market that does not involve inconveniences, such as additional time costs, compared to the conventional gasoline vehicle. Essentially, total time spent per fast charging event can be affected twofold. On the one hand through reducing detour times; and on the other hand by reducing time spent on fast charging itself. This implies that extending fast charging station infrastructure in facilitating EV adoption might have substantial positive welfare effects and facilitate EV adoption. On the other hand, our results imply that shorter charging times at the charging facility should considerably decrease disutility associated with fast charging.

Other valuations obtained from our model are the valuation of $\mathrm{CO} 2$ emissions and the tow hitch facility. Concerning the latter, valuation of this optional facility is pretty homogeneous throughout the consumer segments at the level of $€ 468$ to $€ 574$ per year (all confidence intervals around the point estimates are for the biggest part overlapping). This probably indicates how strong Dutch car drivers value the possibility of using the car for a holiday with a caravan or a trailer.

Concerning the value of reduction of $\mathrm{CO} 2$ emissions, the only segment where we find estimates that are statistically different from zero is the late majority group, valuing it at €98 per ton. This is a relatively high indicator as current price levels for $\mathrm{CO} 2$ at the 
market are fluctuating in the range of $€ 5$ to $€ 15$ per ton (EEX, 2013). Taking its face value would suggest that late majority consumers are highly concerned about the environmental aspect of EV introduction in the form of $\mathrm{CO} 2$ reduction, and they are willing to pay for such reductions. On the other hand, statistically insignificant parameters for $\mathrm{CO} 2$ in other groups suggest that environmental aspect of EV in the form of zero tailpipe emissions may not be that appealing. One of the reasons may be that respondents may question whether zero tailpipe emission means substantial decrease in emissions in view of the entire lifecycle of an EV, and energy production in particular (this argument was mentioned by some respondents during the pilot phase). On the other hand, discarding the environmental aspect as an important determinant of EV adoption based on these results might yet be premature. Our analysis of constructs measuring other facets of environmental characteristics shows that such constructs do prove to be significant in determining EV acceptance among our respondents (this work is yet in progress). Among these constructs are: severity of environmental problems caused by a conventional fossil fuel vehicle including noise and air pollution, depletion of resources; and the efficacy of an electric vehicle to contribute to the solution of these issues.

\section{Conclusions and Implications}

This paper presents results of a stated choice experiment eliciting preferences for full electric vehicles. The experimental design allowed us to distinguish between three phases of EV adoption, and 4 segments of consumers entering the market at different phases. Mean scores on both knowledge and innovativeness constructs were decreasing for respondents in each subsequent adoption segment (the highest scores for the Innovators and the lowest for the Traditionalists) and were significantly different across all segments.

To elicit individual preferences, we have applied a total-cost-of-ownership-anduse approach and included four types of costs to model the utility functions: generalized monetary costs; time costs associated with charging; environmental costs; and costs of supplementary facilities. Our findings show that although all variables proved to be significant in determining respondents' preferences for alternative vehicles in our sample; clear differences in attribute significance that determine individual choices exist across consumer segments. Besides, valuation of costs differs depending on the segment consumers belong to. Consumers in the introductory phase (the innovators and the early adopters) have positive valuation for hybrid vehicles and negative valuation of full electric vehicles relative to conventional vehicles, and their choice is predominantly determined by the time spent on fast charging. The first mass market consumers (the early majority) are similar to early adopters but in addition find a possibility for a tow hitch an important vehicle attribute that should facilitate adoption. For consumers in the maturity stage, the late adopter segment, all shown vehicle attributes are significant in determining their choice. They are the only consumers in this modeled diffusion process who find environmental aspects of EVs of positive influence when making their choices, and for who slow charging brings disutility. Finally, the traditionalists have a strong negative preference for EVs relative to a conventional vehicle, positively value the towing potential 
of the vehicle, and are strongly disturbed by the time spent on fast charging with highest estimated VOT.

Comparing respondent valuations throughout the segments, we conclude that long-term direct monetary incentives might be necessary to facilitate EV adoption (between $€ 900$ and $€ 2,750$ per year, or between $€ 4,500$ and $€ 13,750$ as a one-time subsidy). At the same time, our results show that direct financial advantages that are now available in the Netherlands for hybrid vehicle adoption can be abolished since respondents in all segments are willing to bear additional financial burden associated with hybrid vehicle ownership compared to a gasoline car. These costs may range between $€ 1,460$ and $€ 600$ per year depending on the consumer type. Zero road tax currently applied in the Netherlands to low-emission vehicles (below $50 \mathrm{~g} / \mathrm{km} \mathrm{CO2}$ ) thus seems to be unnecessarily generous. Our results show that limiting road tax exemption to zero tailpipe emission vehicles such as full electric vehicles should suffice the adoption of both EVs and hybrids.

Furthermore, our results suggest that potential consumers of EVs do not see slow charging at home or work as an inconvenience. Rather, consumers in all segments show extremely high disutility from long charging times associated with fast charging events. Obtained estimates are factor 10 higher than conventional estimates of VOT available from the literature. This points at particular importance that respondents place on the fast charging facilities.

Based on this finding, we propose that in facilitating EV adoption a more prominent role should be given as to promoting the installation of the fast charging infrastructure, as to substantial reduction of direct charging times at the facility. Moreover, it is important to bear in mind that this uphill battle has already started: reducing charging time would make current EV users better off, but prospective adopters are even more demanding.

Finally, environmental attribute of an EV (tailpipe CO2 emissions) appears to be not prominent in determining individual choices toward the vehicle; essentially it is triggering adoption only among late majority consumers. The lack of importance that is being attached to this variable may stem from variation in interpretation of this attribute with reference to the lifecycle emissions and energy production. This does not necessarily mean that environmental image as a promoting slogan for EV adoption should be discarded; other dimensions of environmental attribute of an EV such as noise reduction and improvement of air quality may well turn important in determining individual choices. 


\section{References}

Axsen, J., Kurani,K.S., Burke,A. (2010) Are batteries ready for plug-in hybrid buyers? Transport Policy 17(3): 173-182.

Belastingdienst (2012). The Dutch Tax Office, http://www.belastingdienst.nl/rekenhulpen/motorrijtuigenbelasting/ (accessed on 20 Jan 2013).

Beresteanu A., Li S. (2011) Gasoline Prices, Government Support, And The Demand For Hybrid Vehicles In The United States, International Economic Review, 52(1): 161-182.

Bierlaire M. (2003). BIOGEME: A free package for the estimation of discrete choice models, Proceedings of the 3rd Swiss Transportation Research Conference, Ascona, Switzerland.

Bierlaire M. (2008). An introduction to BIOGEME Version 1.6, biogeme.epfl.ch

Bockarjova M., Rietveld P., Verhoef E.T. (2012) Scale, Scope and Cognition: Context Analysis of Multiple Stated Choice Experiments on the Values of Life and Limb. TI Discussion Paper 12046/3. Amsterdam: Tinbergen Institute.

BOVAG-RAI (2012). Mobiliteit in Cijfers. Auto's 2011-12, Amsterdam.

CBS (2011) Statistics Netherlands, http://statline.cbs.nl/StatWeb/dome/?LA=NL (accessed on 28 Jan 2013).

Chandra A., Gulati S., Kandlikar M. (2010) Green drivers or free riders? An analysis of tax rebates for hybrid vehicles, Journal of Environmental Economics and Management, 60:78-93.

Cowan R., Hultin S. (1996) Escaping Lock-In: The Case of the Electric Vehicle, Technological Forecasting and Social Change 53: 61-79.

De Marez Lieven S.B., Verleye Gino B.M. (2004) ICT-innovations today: making traditional diffusion patterns obsolete, and preliminary insight of increased importance, Telematics and Informatics, 21(3):235-260.

Delucchi, M., Wang, Q., Sperling, D. (1989) Electric Vehicles: Performance, Life-Cycle Costs, Emissions, And Recharging Requirements, Transportation Research Part A 3: 255-278.

Dimitropoulos A., Rietveld, P., van Ommeren, J.N. (2012) ConsumerValuationof Driving Range: A Meta-Analysis. Discussion Paper, Tinbergen Institute.

EEX (2013) European energy exchange www.eex.com (accessed on 28 Jan 2013).

Egbue, O., Long, S. (2012) Barriers to widespread adoption of electric vehicles: An analysis of consumer attitudes and perceptions, Energy Policy 48: 717-729.

Eggers F., Eggers F. (2011) Where have all the flowers gone? Forecasting green trends in the automobile industry with a choice-based conjoint adoption model, Technological Forecasting \& Social Change, 78: 51-62.

Franke, T., Neumann, I., Bühler, F., Cocron, P., Krems, J.F. (2012) Experiencing range in an electric vehicle -understanding psychological barriers. Applied Psychology: An International Review, 61(3): 368-391.

Funk, K., Rabl, A. (2002) Electric versus conventional vehicles: social costs and benefits in France, Transportation Research Part D 4: 397-411. 
Hawkins, T.R., Singh, B., Majeau-Bettez, G., Hammer Strømman, A. (2012) Comparative Environmental Life Cycle Assessment of Conventional and Electric Vehicles, Journal of Industrial Ecology 17(1): 53-64.

Hill C.W.L., Jones G.R. (2009) Strategic Management Theory: an Integrative Approach (6 ${ }^{\text {th }}$ ed.). Houghton Mifflin.

Ito, N., Takeuchi, K., Managi, S. (2013) Willingness-to-pay for infrastructure investments for alternative fuel vehicles, Transportation Research Part D 18: 1-8.

Katz M.L., Shapiro, C. (1986) Technology Adoption in the Presence of Network Externalities, Journal of Political Economy, 94(4): 822-41.

Knockaert J., Tseng Y., Verhoef E.T. \& Rouwendal J. (2012) The Spitsmijden experiment: A reward to battle congestion. Transport Policy, 24: 260-272.

Knockaert J., Tseng Y., Verhoef E.T. \& Rouwendal J. (2012) The Spitsmijden experiment: A reward to battle congestion. Transport Policy, 24: 260-272.

Lieven T., Mühlmeier S., Henkel S., Waller J.F. (2011) Who will buy electric cars? An empirical study in Germany, Transportation Research Part D, 16: 236-243.

Lipman, T.E., Delucchi, M.A. (2006) A retail and lifecycle cost analysis of hybrid electric vehicles, Transportation Research Part D, 11: 115-132.

Louviere J.J., Hensher D.A. and Swait J.D. (2000) Stated choice methods: analysis and application, Cambridge University Press.

Maua, P., Eyzaguirrea, J., Jaccarda, M., Collins-Doddb, C., Tiedemanna, K. (2008) The 'neighbor effect': Simulating dynamics in consumer preferences for new vehicle technologies, Ecological Economics 68: 504-516.

Moore G. (1991) Crossing the Chasm; Marketing and selling technology products to mainstream customers ( $2^{\text {nd }}$ ed.). Harper Business Essentials.

RAI (2011) Werkgroep 'Total Cost of Ownership', MEMO 8 februari 2011.

Reuters (2013) EU CO2 prices to treble on supply cut: survey http://www.reuters.com/article/2012/05/30/us-carbon-pwc-surveyidUSBRE84T00720120530 (accessed on 28 Jan 2013).

Rogers E. (2000) Diffusion of Innovation, (5th ed.). New York: Free Press.

Schuitema, G.; Anable, J.; Skippon, S.; Kinnear, N. (2013) The role of instrumental, hedonic and symbolic attributes in the intention to adopt electric vehicles, Transportation Research. Part A 48: 39-49.

Struben J., Sterman J.D. (2008) Transition challenges for alternative fuel vehicle and transportation systems, Environment and Planning B: Planning and Design, 35: 1070-1097.

Train K. (2009) Discrete Choice Methods with Simulation ( $2^{\text {nd }}$ ed.), Cambridge University Press.

Utterback J.M. (1994) Mastering the Dynamics of Innovation. Harvard Business School Press, Boston, Massachusetts.

Vliet van O., Brouwerb A.S., Kuramochib T., Broekb van den M., Faaij A. (2011) Energy use, cost and CO2 emissions of electric cars, Journal of Power Sources 196: 2298-2310. 
Woerdman E. (2004) The Institutional Economics of Market-Based Climate Policy, Developments in Environmental Economics Series, Amsterdam: Elsevier.

Zhang T., Gensler S., Garcia R. (2011) A Study of the Diffusion of Alternative Fuel Vehicles: An Agent-Based Modeling Approach, Journal of Product Innovation and Management, 28: 152168. 


\section{APPENDIX.}

\section{A. Description of the choice situation}

\section{Assume that you are going to buy a car}

You have already made a choice concerning the make and the model of the car.

Currently there are various cars available on the market that use alternative fuels, like hybrid vehicles, electric vehicles, vehicles that drive on hydrogen.

Assume further that technology is developed so that the car model that you have chosen is available with 3 engines:

- as a vehicle with a gasoline engine

- as a vehicle with a hybrid engine

- as a vehicle with a full electric engine

[For Innovators and Early Adopters]: At the moment, about $1 \%$ of cars driving in the Netherlands are hybrid and about $0.1 \%$ full electric. There are fast charging points available throughout the country (about 250 in total), mostly in and around the cities.

[For Early Majority]: Imagine that electric mobility becomes more popular so that about $5 \%$ of the vehicles are full electric (for comparison, it is about double the number of LPG vehicles in the Netherlands at the moment). There are also fast charging points available throughout the country (about the same number of LPG stations now, 450 in total).

[For Late Majority and Traditionalists]: Imagine that electric mobility becomes more popular so that about $10 \%$ of the vehicles are full electric (for comparison, it is about $2 / 3$ the number of diesel vehicles in the Netherlands at the moment). There are also slow and fast charging points available throughout the country: in parking garages, at parking lots by supermarkets and big companies, gas stations.

\section{We will ask you a number of times to make a choice between the three engines available for the car of your choice.}

[a sample card is shown]

We would like to ask you to make 6 choices, in each of which some of the car characteristics will change.

NOTE: please try to consider all shown characteristics when making your choice.

All vehicle characteristics that are not shown should be considered equal.

(for example, the baggage space, the vehicle weight, road taxes due are the same for cars with all types of engines).

[attribute description is shown as provided in Table 1] 
SAMPLE CARD

A car with which engine would you prefer the most?

\begin{tabular}{|c|c|c|c|}
\hline & $\begin{array}{l}\text { Full electric } \\
\text { engine }\end{array}$ & Hybrid engine & Gasoline engine \\
\hline Purchasing price & $€ 15.000$ & $€ 11.000$ & $€ 10.000$ \\
\hline Expected resale price in 5 years & $€ 7.500$ & $€ 5.500$ & $€ 5.000$ \\
\hline $\begin{array}{l}\text { Costs of gasoline / charging (per } 100 \mathrm{~km} \text { ) } \\
\text { (costs in } 5 \text { years based on } 10.000 \mathrm{~km} / \mathrm{y} \text { ) }\end{array}$ & $\begin{array}{l}€ 2.00 \\
(€ 1,000)\end{array}$ & $\begin{array}{l}€ 6.00 \\
(€ 3,000)\end{array}$ & $\begin{array}{l}€ 8.00 \\
(€ 4,000)\end{array}$ \\
\hline $\begin{array}{l}\text { Max range* } \\
\text { Min range* } \\
\text { * number of } k m \text { driven without charging }\end{array}$ & $\begin{array}{l}300 \mathrm{~km} \\
210 \mathrm{~km}\end{array}$ & $\begin{array}{l}900 \mathrm{~km} \\
720 \mathrm{~km}\end{array}$ & $\begin{array}{l}800 \mathrm{~km} \\
720 \mathrm{~km}\end{array}$ \\
\hline $\begin{array}{l}\text { Charging time - at home / work } \\
\text { (per } 100 \mathrm{~km})\end{array}$ & $3 \mathrm{~h}$ & - & - \\
\hline $\begin{array}{l}\text { Charging time }- \text { charging station** } \\
\text { Average detour time** } \\
*_{*}^{*} \text { above the time needed to charge a gazoline } \\
\text { vehicle }\end{array}$ & $\begin{array}{l}15 \mathrm{~min} \\
10 \mathrm{~min}\end{array}$ & - & - \\
\hline Possibility for a tow hitch & yes & no & yes \\
\hline $\begin{array}{l}\text { Average } \mathrm{CO} 2 \text { emissions } \\
\text { (gram per } 1 \mathrm{~km} \text { ) }\end{array}$ & $0 \mathrm{~g} / \mathrm{km}$ & $80 \mathrm{~g} / \mathrm{km}$ & $200 \mathrm{~g} / \mathrm{km}$ \\
\hline Your choice (mark one box please) & $\square$ & 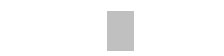 & - \\
\hline
\end{tabular}




\title{
B. Survey questions used for the identification and validation of consumer segments
}

\begin{abstract}
GENERAL INNOVATIVENESS ${ }^{6}$ : The following statements are related to your opinion about innovative products in general. For each of the following statements please mark for how far you agree or disagree with it. (Items measured on a 6-point scale: 0 - entirely disagree to 5 - entirely agree)
\end{abstract}

1. I like to own a innovative product that distinguishes me from others who do not own this new product.

2. Using innovations gives me a sense of personal enjoyment.

3. I love to use innovations that impress others.

4. I prefer to try innovative products with which I can present myself to other people.

5. Acquiring innovative products makes me happier.

6. It gives me a good feeling to possess innovative products.

7. I like to outdo others, and I prefer to do this by buying innovative products which they do not have.

8. Innovative products make my life exciting and stimulating.

9. People I know are influenced by my acceptance of their purchasing the newest products and brands

10. People I know often consult me to help choose the best innovative product available on the market.

11. People I know think it is important that I like the products and brands they buy.

12. People I know frequently gather information from me about a product before they buy one.

KNOWLEDGE: Please indicate for how much you agree with the following statements concerning your knowledge about alternative vehicle technologies (such as fuel cell vehicles, electric or hybrid vehicles). (Items measured on a 6-point scale: 0 - entirely disagree to 5 - entirely agree).

1. I have knowledge about alternative vehicle technologies.

2. I know which advantages and disadvantages alternative vehicle technologies have compared to a gasoline vehicle.

3. I can explain which differences there are between alternative vehicle technologies and a gasoline vehicle (for example, in terms of environmental effects, functionality)

CONSUMER SEGMENTS: Imagine that you are going to buy a new car. Which of the following narratives describe you the best? (choose one of the following statements)

1. I am a type of person who closely follows new technological developments and who dares taking risks by being the first one to purchase an innovative vehicle.

2. I am a type of person who envisions potential advantages in an innovative vehicle and who is one of the first to make use of these advantages and to profit from those.

3. I am a type of person who is interested in innovative vehicles but at the same time is pragmatic. First I would like to take time and be persuaded about the advantages that an innovative vehicle possesses. My decisions are (mainly) based on the recommendations of existing users.

4. I am a type of person who is not thrilled by innovative vehicles, but who appreciates security. It is safe to purchase an innovative vehicle when it has been on the market for some while and offers obvious advantages.

5. I am a type of person who has little affiliation with innovative vehicles; such vehicles should first prove themselves on the market. I do not like change and I purchase an innovative vehicle only when the existing model is not produced anymore.

\footnotetext{
${ }^{6}$ Items 1 - 8 are based on the scale developed by Vandecasteele and Geuens (2010), items $9-12$ are based on the scale developed by Jager (2009).
} 


\section{Survey questions used for obtaining total costs of ownership}

SLOW/FAST CHARGING: Imagine that you would choose to drive a full electric vehicle. Such vehicle can be charged slow or fast:

Slow charging is charging from a socket. It takes time (several hours), but may take place at the moments when the car is not being driven. It is cheap, and requires no detour.

Fast charging is much faster, but you need to drive to a special charging station, and it is more expensive. Take a look at the overview in the following table: ${ }^{7}$

For Innovators and Early Adopters:

\begin{tabular}{|l|c|c|}
\hline & $\begin{array}{c}\text { Charging at } \\
\text { home / work }\end{array}$ & $\begin{array}{c}\text { Station charging } \\
\text { (fast charging) }\end{array}$ \\
\hline Charging time (per 100 km) & ab. 3.5h & ab. 30min \\
\hline Ave.detour and waiting time & 0 & $20 \mathrm{~min}$ \\
\hline $\begin{array}{l}\text { Ave.costs of charging } \\
\text { (per 100km range) }\end{array}$ & 3 euro & $3.60 \mathrm{euro}$ \\
\hline
\end{tabular}

For Early Majority:

\begin{tabular}{|l|c|c|}
\hline & $\begin{array}{c}\text { Charging at } \\
\text { home / work }\end{array}$ & $\begin{array}{c}\text { Station charging } \\
\text { (fast charging) }\end{array}$ \\
\hline Charging time (per 100 km) & ab. 2.5h & ab. 20min \\
\hline Ave.detour and waiting time & 0 & $15 \mathrm{~min}$ \\
\hline $\begin{array}{l}\text { Ave.costs of charging } \\
\text { (per 100km range) }\end{array}$ & 3 euro & 3.60 euro \\
\hline
\end{tabular}

For Late Majority and Traditionalists:

\begin{tabular}{|l|c|c|}
\hline & $\begin{array}{c}\text { Charging at } \\
\text { home / work }\end{array}$ & $\begin{array}{c}\text { Station charging } \\
\text { (fast charging) }\end{array}$ \\
\hline Charging time (per 100 km) & ab. $2 \mathrm{~h}$ & ab. 15min \\
\hline Ave.detour and waiting time & 0 & $10 \mathrm{~min}$ \\
\hline $\begin{array}{l}\text { Ave.costs of charging } \\
\text { (per 100km range) }\end{array}$ & 3 euro & 3.60 euro \\
\hline
\end{tabular}

If you choose to drive a full electric vehicle, how often would you expect to make use of fast charging in order to charge your car, in \% relative to the total number of charging times.

$0-$ means making NO use of fast charging; only slow charging.

100 - means ONLY fast charging.

A slider was shown where respondents could move it on an integer continuum between 0 and 100.

How often would you expect to make use of fast charging?

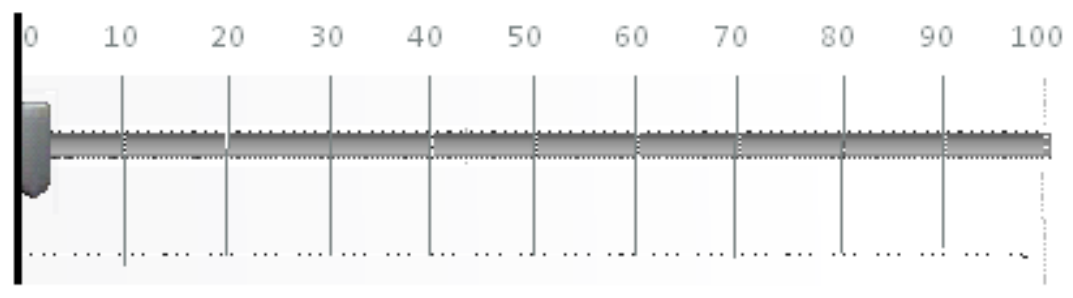

\footnotetext{
${ }^{7}$ Values in the tables below are average vehicle characteristics per adoption stage that appeared on the experiment cards.
} 
PRICE: How much would you expect to spend on the purchase of your next car? (that is, the purchasing price without considering a potential exchange)

Values shown to respondents intending to buy a new car:

below $10.000 €$

○ $10.000 €$ to $15.000 €$

○ $15.000 €$ to $20.000 €$

○ $20.000 €$ to $25.000 €$

O $25.000 €$ to $30.000 €$

O $30.000 €$ to $35.000 €$

O $35.000 €$ to $40.000 €$

O $40.000 €$ to $45.000 €$

O $45.000 €$ to $50.000 €$

O More than $50.000 €$

Values shown to respondents intending to buy a used car:

O below $5.000 €$

○ $5.000 €$ to $7.500 €$

○ $7.500 €$ to $10.000 €$

○ $10.000 €$ to $12.500 €$

○ $12.500 €$ to $15.000 €$

○ $15.000 €$ to $17.500 €$

○ $17.500 €$ to $20.000 €$

○ $20.000 €$ to $22.500 €$

○ $22.500 €$ to $25.000 €$

○ More than $25.000 €$

KM: How many kilometers per year do you expect to drive with your next / new car?

O Less than $5.000 \mathrm{~km}$

O 5.000 to $10.000 \mathrm{~km}$

O 10.000 to $15.000 \mathrm{~km}$

O 15.000 to $20.000 \mathrm{~km}$

O 20.000 to $25.000 \mathrm{~km}$

O 20.000 to $25.000 \mathrm{~km}$

O 25.000 to $30.000 \mathrm{~km}$

O 30.000 to $35.000 \mathrm{~km}$

O 35.000 to $40.000 \mathrm{~km}$

O 40.000 to $45.000 \mathrm{~km}$

O 45.000 to $50.000 \mathrm{~km}$

O Other, namely 


\section{Tables}

TABLE A1. Attribute levels per car type and adoption phase

\begin{tabular}{|c|c|c|c|c|c|c|c|c|c|}
\hline & \multicolumn{3}{|c|}{$\begin{array}{c}\text { INTRODUCTION PHASE } \\
\text { (Innovators and Early Adopters) }\end{array}$} & \multicolumn{3}{|c|}{$\begin{array}{l}\text { MASS MARKET PHASE } \\
\text { (Early Majority) }\end{array}$} & \multicolumn{3}{|c|}{$\begin{array}{c}\text { MATURITY PHASE } \\
\text { (Late Majority and Traditionalists) }\end{array}$} \\
\hline & $\begin{array}{l}\text { Full electric } \\
\text { engine }\end{array}$ & $\begin{array}{l}\text { Hybrid } \\
\text { engine }\end{array}$ & $\begin{array}{l}\text { Gasoline } \\
\text { engine }\end{array}$ & $\begin{array}{l}\text { Full electric } \\
\text { engine }\end{array}$ & $\begin{array}{l}\text { Hybrid } \\
\text { engine }\end{array}$ & $\begin{array}{l}\text { Gasoline } \\
\text { engine }\end{array}$ & $\begin{array}{l}\text { Full electric } \\
\text { engine }\end{array}$ & $\begin{array}{l}\text { Hybrid } \\
\text { engine }\end{array}$ & $\begin{array}{l}\text { Gasoline } \\
\text { engine }\end{array}$ \\
\hline $\begin{array}{l}\text { Expected resale price } \\
\text { in } 5 \text { years, in } € \\
\text { (\% of purch.price) }\end{array}$ & $\begin{array}{l}40 \% \\
50 \% \\
60 \% \\
\end{array}$ & $\begin{array}{l}40 \% \\
50 \% \\
60 \% \\
\end{array}$ & $\begin{array}{l}40 \% \\
50 \% \\
60 \% \\
\end{array}$ & $\begin{array}{l}40 \% \\
50 \% \\
60 \% \\
\end{array}$ & $\begin{array}{l}40 \% \\
50 \% \\
60 \% \\
\end{array}$ & $\begin{array}{l}40 \% \\
50 \% \\
60 \% \\
\end{array}$ & $\begin{array}{l}40 \% \\
50 \% \\
60 \% \\
\end{array}$ & $\begin{array}{l}40 \% \\
50 \% \\
60 \% \\
\end{array}$ & $\begin{array}{l}40 \% \\
50 \% \\
60 \% \\
\end{array}$ \\
\hline $\begin{array}{l}\text { Costs of fuel / charging } \\
\text { (€ per } 100 \mathrm{~km})\end{array}$ & $\begin{array}{l}€ 2.00 \\
€ 3.00 \\
€ 4.00\end{array}$ & $\begin{array}{c}€ 6.00 \\
€ 9.00 \\
€ 12.00 \\
\end{array}$ & $\begin{array}{l}€ 8.00 \\
€ 12.00 \\
€ 16.00 \\
\end{array}$ & $\begin{array}{l}€ 2.00 \\
€ 3.00 \\
€ 4.00 \\
\end{array}$ & $\begin{array}{c}€ 5.00 \\
€ 7.50 \\
€ 10.00 \\
\end{array}$ & $\begin{array}{r}€ 6.00 \\
€ 9.00 \\
€ 12.00 \\
\end{array}$ & 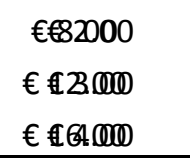 & $\begin{array}{c}€ 5.00 \\
€ 7.50 \\
€ 10.00 \\
\end{array}$ & $\begin{array}{c}€ 6.00 \\
€ 9.00 \\
€ 12.00 \\
\end{array}$ \\
\hline $\begin{array}{l}\text { (costs of fuel / charging } \\
\text { in } 5 \text { years based on xxx } \\
\mathrm{km} / \mathrm{y} \text {, in } € / \mathrm{y} \text { ) }\end{array}$ & $\begin{array}{l}\text { Customized } \\
\text { ( } 3 \text { levels) }\end{array}$ & $\begin{array}{l}\text { Customized } \\
\text { ( } 3 \text { levels) }\end{array}$ & $\begin{array}{l}\text { Customized } \\
\text { ( } 3 \text { levels) }\end{array}$ & $\begin{array}{l}\text { Customized } \\
\text { (3 levels) }\end{array}$ & $\begin{array}{l}\text { Customized } \\
\text { ( } 3 \text { levels) }\end{array}$ & $\begin{array}{l}\text { Customized } \\
\text { (3 levels) }\end{array}$ & $\begin{array}{l}\text { Customized } \\
\text { ( } 3 \text { levels) }\end{array}$ & $\begin{array}{l}\text { Customized } \\
\text { ( } 3 \text { levels) }\end{array}$ & $\begin{array}{l}\text { Customized } \\
\text { (3 levels) }\end{array}$ \\
\hline $\begin{array}{l}\text { Min range }(\mathrm{km}) \\
\text { (\% of max range) }\end{array}$ & $\begin{array}{l}60 \% \\
70 \% \\
80 \% \\
\end{array}$ & $\begin{array}{l}70 \% \\
80 \% \\
90 \% \\
\end{array}$ & $\begin{array}{l}70 \% \\
80 \% \\
90 \% \\
\end{array}$ & $\begin{array}{l}400 \% \\
500 \% \\
680 \%\end{array}$ & $\begin{array}{l}70 \% \\
80 \% \\
90 \%\end{array}$ & $\begin{array}{l}70 \% \\
80 \% \\
90 \%\end{array}$ & $\begin{array}{l}460 \% \\
500 \% \\
680 \% \\
\end{array}$ & $\begin{array}{l}70 \% \\
80 \% \\
90 \% \\
\end{array}$ & $\begin{array}{l}70 \% \\
80 \% \\
90 \% \\
\end{array}$ \\
\hline $\begin{array}{l}\text { Charging time }- \text { at home } \\
\text { / work }(\mathrm{h} / 100 \mathrm{~km})\end{array}$ & $\begin{array}{c}2 \\
3.5 \\
5\end{array}$ & - & - & $\begin{array}{c}1 \\
2.5 \\
4\end{array}$ & - & - & $\begin{array}{c}0.5 \\
2 \\
3.5\end{array}$ & - & - \\
\hline
\end{tabular}


TABLE A1. Attribute levels per car type and adoption phase (continued)

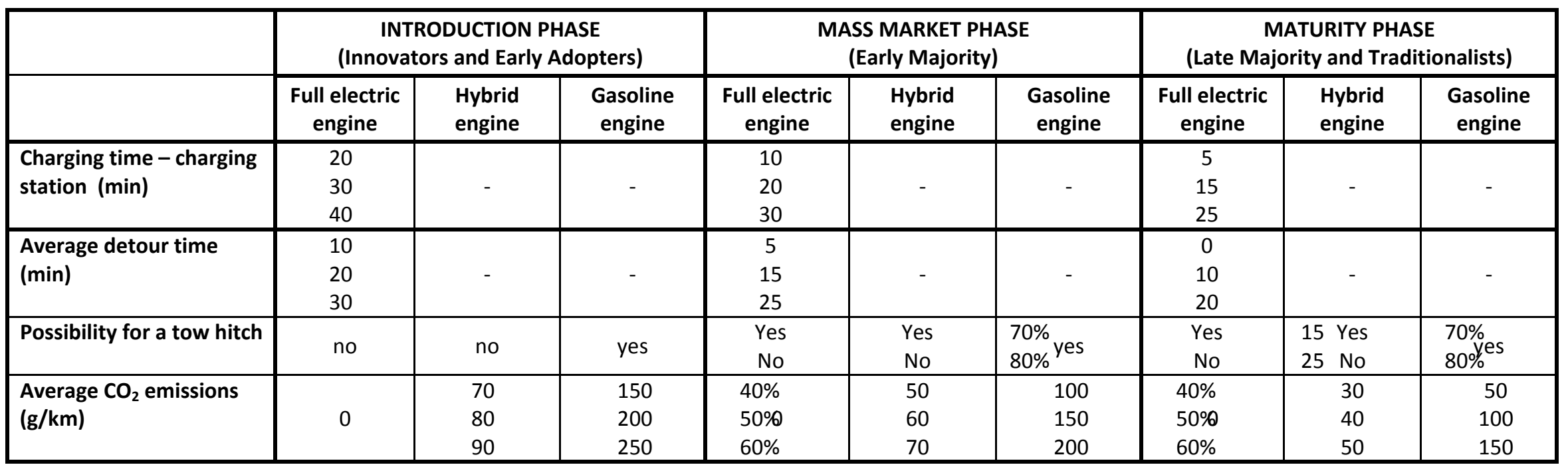

${ }^{a}$ Levels of the purchasing price attribute were customized based on the intended purchasing price indicated by a respondent with steps of $€ 500$ for used vehicles and with steps of $€ 1000$ for new vehicles. 
TABLE A2. Average attribute values per vehicle type and adoption phase

\begin{tabular}{|c|c|c|c|c|c|c|c|c|c|}
\hline & \multicolumn{3}{|c|}{$\begin{array}{c}\text { INTRODUCTION PHASE } \\
\text { (Innovators and Early Adopters) }\end{array}$} & \multicolumn{3}{|c|}{$\begin{array}{l}\text { MASS MARKET PHASE } \\
\text { (Early Majority) } \\
\end{array}$} & \multicolumn{3}{|c|}{$\begin{array}{c}\text { MATURITY PHASE } \\
\text { (Late Majority and Traditionalists) }\end{array}$} \\
\hline & $\begin{array}{l}\text { Full electric } \\
\text { engine }\end{array}$ & $\begin{array}{l}\text { Hybrid } \\
\text { engine }\end{array}$ & $\begin{array}{l}\text { Gasoline } \\
\text { engine }\end{array}$ & $\begin{array}{c}\text { Full electric } \\
\text { engine }\end{array}$ & $\begin{array}{l}\text { Hybrid } \\
\text { engine }\end{array}$ & $\begin{array}{l}\text { Gasoline } \\
\text { engine }\end{array}$ & $\begin{array}{c}\text { Full electric } \\
\text { engine }\end{array}$ & $\begin{array}{l}\text { Hybrid } \\
\text { engine }\end{array}$ & $\begin{array}{l}\text { Gasoline } \\
\text { engine }\end{array}$ \\
\hline Purchasing price (in $€$ ) & $€ 21,547$ & $€ 16,688$ & $€ 14,406$ & $€ 16,342$ & $€ 13,538$ & $€ 11,741$ & $€ 11,804$ & $€ 10,570$ & $€ 9,155$ \\
\hline $\begin{array}{l}\text { Costs of gazoline / charging } \\
\text { (in € per } 100 \mathrm{~km} \text { ) }\end{array}$ & $€ 3$ & $€ 9$ & $€ 12$ & $€ 3$ & $€ 7.5$ & $€ 9$ & $€ 3$ & $€ 7.5$ & $€ 9$ \\
\hline $\begin{array}{l}\text { Costs in } 5 \text { years based on } \\
10.000 \mathrm{~km} / \mathrm{y} \text { (in € per year) }\end{array}$ & $€ 3,010$ & $€ 9,296$ & $€ 12,442$ & $€ 2,721$ & $€ 7,022$ & $€ 8,414$ & $€ 2,435$ & $€ 6,320$ & $€ 7,560$ \\
\hline $\begin{array}{l}\text { Expected resale price } \\
\text { in } 5 \text { years (in } € \text { ) }\end{array}$ & $€ 10,825$ & $€ 8,294$ & $€ 7,213$ & $€ 8,220$ & $€ 6,754$ & $€ 5,872$ & $€ 5,950$ & $€ 5,261$ & $€ 4,578$ \\
\hline Max range $(\mathrm{km})$ & 200 & 800 & 700 & 300 & 800 & 700 & 400 & 800 & 700 \\
\hline Min range $(\mathrm{km})$ & 140 & 640 & 560 & 210 & 640 & 560 & 280 & 640 & 560 \\
\hline $\begin{array}{l}\text { Charging time - at home / work } \\
\text { (h / 100km) }\end{array}$ & 3.5 & - & - & 2.5 & - & - & 2.0 & - & - \\
\hline $\begin{array}{l}\text { Charging time - charging } \\
\text { station (min) }\end{array}$ & 30 & - & - & 20 & - & - & 15 & - & - \\
\hline Average detour time (min) & 20 & - & - & 15 & - & - & 10 & - & - \\
\hline Possibility for a tow hitch & no & no & yes & 0.50 & 0.50 & 1 & 0.50 & 0.50 & 1 \\
\hline Average $\mathrm{CO} 2$ emissions $(\mathrm{g} / \mathrm{km})$ & 0 & 80 & 200 & 0 & 60 & 150 & 0 & 40 & 100 \\
\hline
\end{tabular}


